\title{
REKURS HIERARCHICZNY DO DYKASTERII KURII RZYMSKIEJ
}

\begin{abstract}
Streszczenie. Kodeks prawa kanonicznego z 1983 r., normując przepisy dotyczące rekursu hierarchicznego, nie odnosi ich wyłącznie do Kongregacji Kurii Rzymskiej, ale każdego wyższego hierarchicznie organu administracji. Przedmiotem zainteresowania autora jest rekurs do Kurii Rzymskiej, następujący po wyczerpaniu niższej drogi hierarchicznej. Zgodnie z kan. 1737 § 1 Kodeksu prawa kanonicznego każdy, kto czuje się poszkodowany jakimś aktem administracyjnym, ma prawo złożenia rekursu do przełożonego hierarchicznego autora aktu administracyjnego. Dlatego też $\mathrm{w}$ artykule poruszane są kwestie motywu, przedmiotu, podmiotu rekursu, jak i samej procedury rozpatrzenia rekursu do Kurii Rzymskiej.
\end{abstract}

Słowa kluczowe: rekurs, Kuria Rzymska, dekret, akt administracyjny, procedura.

Rekurs hierarchiczny, będący rekursem administracyjnym złożonym do organu administracyjnie wyższego w stosunku do tego, który wydał zaskarżany akt, istniał od początku Kościoła. W pierwszych wiekach chrześcijaństwa trudno jednak mówić o rekursach hierarchicznych $\mathrm{w}$ ścisłym sensie z tej racji, iż nie istniało precyzyjne oddzielenie drogi administracyjnej od drogi sądowej (McClunn 1946, 72). Rekurs hierarchiczny zyskał na znaczeniu po dokonanej przez papieża Sykstusa V w latach 1587-1588 reformie Kurii Rzymskiej, kiedy to kompetencje rozstrzygania sporów administracyjnych zostały powierzone różnym kongregacjom, w tym w sposób szczególny Kongregacji Soboru. Wydana w 1908 r. Konstytucja Sapienti consilio potwierdziła istotną rolę rekursu hierarchicznego w jurysdykcji Kościoła (Pius X 1909). Zarówno w Lex propria S. Romanae Rotae ac Signaturae Apostolicae, wydanym w następstwie konstytucji Sapienti consilio, jak i promulgowanym w 1917 r. Kodeksie prawa kanonicznego został określony zakaz wnoszenia apelacji od decyzji ordynariuszy do Roty Rzymskiej, przydzielając kompetencje do rozstrzygania takich sporów kongregacjom rzymskim (kan. 1601 CIC)1.

Kodeks prawa kanonicznego z 1983 r., mówiąc o rekursie hierarchicznym, nie ogranicza go jedynie do rekursu do kongregacji Kurii Rzymskiej, jak to było w starym prawie kodeksowym, lecz odnosi go do każdego rekursu składanego do organu administracyjnie wyższego od organu będącego autorem aktu. Przedmiotem naszego zainteresowania jest jednak rekurs hierarchiczny składany do

* Uniwersytet Łódzki, Wydział Prawa i Administracji, Katedra Teorii i Filozofii Prawa, gleszczynski@wpia.uni.lodz.pl.

1 "Contra Ordinariorum decreta non datur appellatio seu recursus ad Sacram Rotam; sed de eiusmodi recursibus exclusive cognoscunt Sacra Congregationes". 
dykasterii Kurii Rzymskiej po wyczerpaniu drogi hierarchicznej niższych szczebli. Oznacza to, że w niniejszym artykule podejmiemy kwestię działalności kontrolnej najwyższego szczebla administracji Kościoła, działającej w imieniu Biskupa Rzymskiego (Joannes Paulus II 1988, art. 2), zamykającej drogę administracyjną rozstrzygania sporów wynikłych wskutek wydania aktu administracyjnego, od której decyzji istnieje wyłącznie możliwość wniesienia rekursu sądowoadministracyjnego do II sekcji Sygnatury Apostolskiej.

\section{PODMIOT REKURSU HIERARCHICZNEGO}

Zgodnie z kan. 1737 § 1 KPK każdy, kto twierdzi, że jest pokrzywdzony dekretem, może wnieść rekurs do hierarchicznego przełożonego tego, kto wydał dekret² Tak sformułowana norma kan. $1737 \S 1$ wyznacza zatem podmioty sporu administracyjnego, który staje się przedmiotem jego zaskarżenia do organu hierarchicznie wyższego od organu będącego autorem aktu. Podmioty te to: autor rekursu, autor zaskarżonego aktu oraz organ administracyjny, który ma rozpatrzyć rekurs do niego złożony.

\subsection{Podmiot ad quem}

Podmiotem ad quem w przypadku rekursu wniesionego do dykasterii Kurii Rzymskiej jest oczywiście kompetentna do jego rozpatrzenia dykasteria. Należy w tym miejscu zauważyć, że wniesienie tegoż rekursu do dykasterii Kurii Rzymskiej jest warunkiem koniecznym do dalszego postępowania na drodze sądowoadministracyjnej w II sekcji Sygnatury Apostolskiej. Oznacza to, że osoba, która czuje się pokrzywdzona dekretem lub innym aktem administracyjnym, nie może wstąpić na drogę sądowoadministracyjną, jeśli nie została wyczerpana droga administracyjna, której ostatnim stadium jest właśnie rekurs hierarchiczny do kompetentnej dykasterii Kurii Rzymskiej. Wynika to jasno z art. $123 \S 1$ Konstytucji Pastor bonus oraz z art. 136 § 4 Ogólnego Regulaminu Kurii Rzymskiej (Regolamento generale della Curia Romana 1999), o ile Biskup Rzymski nie zechce przesłać zaskarżonego aktu bezpośrednio do Sygnatury Apostolskiej (Joannes Paulus II 1988, art. 123 § 3).

Podmiotem ad quem, o którym mowa, nie jest wyłącznie jedna z kongregacji rzymskich, ale w szerszym tego słowa znaczeniu - jak wynika z art. 19 $\S 1$ Pastor bonus - jedna z dykasterii ${ }^{3}$. W tym względzie Konstytucja Pastor bonus jednoznacznie określa kompetencje poszczególnych kongregacji i dykasterii.

${ }^{2}$ "Qui se decreto gravatum esse contendit, potest ad Superiorem hierarchicum eius, qui decretum tulit, propter quodlibet iustum motivum recurrere $[\ldots]$ ".

${ }^{3}$ „Recursus hierarchici a Dicasterio recipiuntur, quod competens sit ratione materiae, firmo praescripto art. $21 \S 1$ ". 
Analizując działalność różnych dykasterii w ostatnich latach, nietrudno zauważyć, że najczęściej rekursy hierarchiczne wnoszone do Kongregacji ds. Instytutów Życia Konsekrowanego i Stowarzyszeń Życia Apostolskiego oraz do Kongregacji ds. Duchowieństwa (Miras, Canosa, Baura 2007, 337).

Pomimo wskazań Konstytucji Pastor bonus, określających kompetencje poszczególnych dykasterii Kurii Rzymskiej, dla przeciętnego wiernego ukierunkowanie rekursu nie zawsze jest łatwe. Co istotne, pomyłka w tym względzie, zgodnie z praktyką Kurii Rzymskiej, nie oznacza oddalenia rekursu, ale jego przekazanie do dykasterii właściwej (Labandeira 1991, 94).

Możliwa jest również sytuacja, że więcej niż jedna dykasteria jest kompetentna do rozpatrzenia danego rekursu. W takiej sytuacji możliwe jest wniesienie rekursu do jednej z nich lub nawet do wszystkich (Marchesi 1996, 86). Zgodnie $\mathrm{z}$ art. 20 Pastor bonus o tym, która z dykasterii winna rozpatrzyć rekurs decyduje Sygnatura Apostolska ${ }^{4}$.

\subsection{Podmiot czynny rekursu}

Podmiotem czynnym rekursu może być zarówno osoba fizyczna, jak i prawna, która twierdzi, że została pokrzywdzona dekretem lub innym aktem administracyjnym. W tym względzie wymagana jest nie tylko ogólna zdolność prawna do podejmowania czynności i działań prawnych w Kościele, lecz przede wszystkim legitymizacja do występowania w konkretnej sprawie.

Osoba fizyczna ma prawo złożenia rekursu hierarchicznego, o ile jest pełnoletnia. W przypadku osoby małoletniej, jak i zrównanej z nią, prawo to może wypełnić ona za pośrednictwem rodziców lub opiekunów. Co ważne, w myśl kan. 1476-1479 $\mathrm{KPK}^{5}$, prawo złożenia rekursu ma nie tylko wierny, ale również osoba nieochrzczona (Moneta 1991, 56).

Osoba prawna ma zdolność występowania jako podmiot czynny rekursu, o ile posiada osobowość prawną, prywatną lub publiczną (Navarro 1993, 70-71). Norma ta ma swoje konsekwencje w odniesieniu do stowarzyszeń lub innych grup, które nie posiadają osobowości prawnej. Jak wynika z odpowiedzi, którą Papieska Komisja ds. Interpretacji Autentycznej Kodeksu Prawa Kanonicznego udzieliła w dniu 20 czerwca 1987 r. grupie wiernych nieposiadających osobowości prawnej w Kościele, stowarzyszenia lub inne grupy nieposiadające osobowości prawnej nie mogą być podmiotem czynnym rekursu (Pontificia Commissio Codicis Iuris Canonici Authentice Interpretando 1988, 1818)6. W odpowiedzi tej, mającej charakter

${ }^{4}$ „Conflictus competentiae inter Dicasteria, si qui oriantur, Supremo Tribunali Signaturae Apostolicae subiciantur, nisi Summo Pontifici aliter prospiciendum placuerit".

${ }^{5}$ Kan. 1476: „Quilibet, sive baptizatus sive non baptizatus, potest in iudicio agere; pars autem legitime conventa respondere debet”.

${ }^{6}$ Responsum 20.06.1987: „Utrum christifidelium coetus, personalitatis iuridicae, immo et recognitionis de qua in can. $299 \S 3$, expers, legitimationem activam habeat ad recursum hierarchicum 
czysto formalistyczny, zdaniem G. Lo Castro nie dostrzega się grup wiernych, które pomimo iż nie posiadają osobowości prawnej, swoim działaniem wnoszą wiele dynamizmu do organizmu, jakim jest Kościół (Lo Castro 1985, 110).

Drugim warunkiem kształtującym prawo do wniesienia rekursu jest legitymizacja odnosząca się do konkretnej sprawy. Legitymizacja ta wynika z faktu, że dana osoba fizyczna lub prawna, znajdując się w zasięgu oddziaływania dekretu administracyjnego uważa, iż dekret ten powoduje pogorszenie jej sytuacji w Kościele, naruszenie uprawnień, jakie jej się należą, pozbawia ją dóbr, z których dotychczas korzystała (Krukowski 1985, 210-211). Mowa zatem o interesie osobistym danej osoby, który w jej przeświadczeniu został naruszony konkretnym aktem administracyjnym. Naruszenie to winno mieć charakter aktualny i osobisty. Oznacza to, że dotyczy ono danej osoby, nie zaś osób trzecich oraz trwa aktualnie (Ranaudo 1968, 558). W tym względzie należy zauważyć, że w przypadku dekretu, mocą którego zostaje zniesiona jakaś parafia, wierni zamieszkujący na jej terenie mają legitymizację do wniesienia rekursu przeciw dekretowi biskupa diecezji. Nie mają natomiast takiej legitymizacji w odniesieniu do dekretu biskupa diecezji, mocą którego zostaje usunięty z ich parafii proboszcz, gdyż w bezpośredni sposób dekret narusza interes proboszcza, nie zaś wiernych (Miras, Canosa, Baura 2007, 335).

Ogólny Regulamin Kurii Rzymskiej w art. 138 odnosi do rekursów składanych w dykasteriach Kurii Rzymskiej normę zawartą w kan. 1738 KPK. Zgodnie z normą kan. $1738 \mathrm{KPK}^{7}$ osoba wnosząca rekurs ma bowiem zawsze prawo posłużyć się adwokatem lub pełnomocnikiem; co więcej, obrońca powinien być ustanowiony z urzędu, jeśli wnoszący rekurs nie ma obrońcy, a dykasteria uzna to za konieczne (Joannes Paulus II 1988, art. 183). Norma zawarta w kan. 1738 przywołuje zatem normę ogólną zawartą w kan. $1481 \S 1 \mathrm{KPK}^{8}$, w myśl której strona może swobodnie ustanowić sobie adwokata i pełnomocnika (D’Ostilio 1996, 474) $)^{9}$. Jak się wydaje, nie ma absolutnego obowiązku skorzystania czy też ustanowienia obrońcy, jednak jest to użyteczne z powodu braku wiedzy wiernych co do praktyki Kurii Rzymskiej, jak również zagwarantowania technicznej

proponendum adversus decretum proprii Episcopi dioecesani. R. Negative, qua coetus; affirmative, qua singuli christifideles, sive singillatinam sive coniunctum agentes, dummodo revera gravamen passi sint. In aestimatione autem huius gravaminis, iudex congrua discretionalitate gaudeat oportet".

${ }^{7}$ Kan. 1738: „Reccurens semper ius habet advocatum vel procuratorem adhibendi, vitatis inutilibus moris; immo vero patronus ex officio constituatur, si reccurens patrono careat et Superior id necessarium conseat; semper tamen potest Superior magis expedire videatur, emendare, subrogare, ei ebrogare".

${ }^{8}$ Kan. $1481 \S 1$ : „Pars libere potest advocatum et procuratorem sibi constituere; sed praeter casus in $\S \S 2$ et 3 statutos, potest etiam per se ipsa agere et respondere, nisi iudex procuratoris vel advocati ministerium necessarium exstimaverit".

${ }^{9}$ „La possibilità di poter essere assistito dall'avvocato significa dare al ricorrente la possibilità di difendere adeguatamente il proprio diritto, a livello di ricorso gerarchico [...] significa anche il dare al ricorso gerarchico una nuova dimensione, per quanto concerne la difesa del diritto soggettivo dei privati di fronte ai provedimenti delle Autorità amministrative". 
i profesjonalnej obrony własnych interesów. Istotnym argumentem za ustanowieniem adwokata jest też fakt, że osoba wnosząca rekurs zwykle zamieszkuje z dala od Rzymu i nie do końca jest w stanie czuwać nad ochroną własnych praw podczas procedury rozpatrzenia rekursu (Miras, Canosa, Baura 2007, 335).

Do adwokata i pełnomocnika, o których mowa w kan. 1738 KPK, odnoszą się również normy zawarte w kan. 1481-1490 KPK, w szczególności zaś te, które dotyczą prawa do przeglądania akt, proponowania dowodów, jak i zaznajomienia się z nimi w trakcie trwania postępowania.

\subsection{Podmiot bierny rekursu}

Podmiotem biernym rekursu hierarchicznego, czyli pars resistens, jest organ, który wydał zaskarżony akt administracyjny. W przypadku aktu wydanego przez organ administracyjny, którego wyższym przełożonym hierarchicznym jest dykasteria rzymska, określenie podmiotu biernego rekursu nie stwarza problemów interpretacyjnych. Wątpliwość powstaje wówczas, gdy akt wydany przez tenże organ administracyjny jest aktem rozstrzygającym spór administracyjny, a więc aktem będącym odpowiedzią na wcześniejszy rekurs hierarchiczny wniesiony przeciwko aktowi organu hierarchicznie niższego. W tym przypadku rodzi się bowiem pytanie, czy podmiotem biernym rekursu do dykasterii Kurii Rzymskiej jest pierwotny autor aktu administracyjnego, czy też organ potwierdzający tenże w akt w drodze rekursu hierarchicznego. Zdania autorów w tym względzie nie są jednoznaczne. Wydaje się jednak, że również w omawianym przypadku podmiotem biernym rekursu jest organ bezpośrednio niższy w stosunku do dykasterii rzymskiej, a więc ten, który potwierdził zaskarżony wcześniej akt administracyjny. Taka interpretacja pośrednio wynika z normy zawartej w art. $123 \S 1$ Konstytucji Pastor bonus.

Należy w tym miejscu zauważyć, że podmiotem biernym rekursu nie może być ani Biskup Rzymski, ani sobór powszechny (kan. 1732 KPK). Podobnie nie może nim być żadna z dykasterii Kurii Rzymskiej, gdyż w tym przypadku możliwa jest jedynie droga sądowoadministracyjna (kan. 331, 1372, 1404, 1405 § 2, $16291^{\circ} \mathrm{KPK}$ ).

\section{MOTYW REKUSRU HIERARCHICZNEGO}

W myśl kan. 1737 § 1 KPK rekurs hierarchiczny może być wniesiony z jakiegokolwiek słusznego motywu (quodlibet iustum motivum). W tym względzie należy jednak wyróżnić tzw. motyw formalny (causa petendi) oraz motyw podmiotowy (petitum). 


\subsection{Motyw formalny (causa petendi)}

Użyty w kan. $1737 \S 1 \mathrm{KPK}$ termin quodlibet sugeruje, iż prawodawca, mówiąc o motywie formalnym rekursu hierarchicznego, nie ogranicza go jedynie do nielegalności aktu administracyjnego, lecz wskazuje również na jego niewłaściwość w sensie merytorycznym, a także jego niestosowność (Gullo 1991, 86-87).

Nielegalność aktu administracyjnego wynika z naruszenia normy prawnej pozytywnej lub naturalnej, a nawet zwyczajowej i może dotyczyć jakiegokolwiek elementu, który uczestniczy w tworzeniu aktu, a więc podmiotu, przedmiotu, przyczyny, celu, formy lub innego przymiotu wymaganego do jego ważności (Labandeira 1994, 580). Naruszenie prawa, o którym mowa, w myśl art. $123 \S 1$ Konstytucji apostolskiej Pastor bonus może dotyczyć zarówno samej decyzji, jak i procesu tworzenia aktu (art. $123 \S 1^{10}$ ).

Precyzyjne określenie motywów rekursu opartych na jego nieużyteczności lub niestosowności nie jest proste. Owa nieużyteczność czy też niestosowność jakiegoś aktu administracyjnego może być postrzegana subiektywnie lub wręcz emocjonalnie. Jakiś akt administracyjny jest niestosowny, jeśli nie ma zdolności osiągnięcia celu społecznego, jaki od niego należy wymagać. Aby jednak ów akt mógł stanowić przedmiot rekursu, winien być nie tylko niestosowny, ale przede wszystkim nieużyteczny i szkodliwy. Potwierdza to norma zawarta zarówno w art. $19 \S 1$ Konstytucji apostolskiej Pastor bonus, jak i w art. $136 \S 1$ Ogólnego Regulaminu Kurii Rzymskiej z 1999 r. ${ }^{11}$ Jak zauważa J. Krukowski, osoba wnosząca rekurs winna wskazać obiektywną normę prawną, która jej zdaniem została naruszona przez akt administracyjny; ewentualnie wskazać racje obiektywne, z których wynika, iż dany akt jest przejawem arbitralności organu kościelnej władzy administracyjnej czy wykazać jego nieużyteczność, a nawet wręcz szkodliwość dla dobra publicznego Kościoła (Krukowski 1985, 213-214).

\subsection{Motyw podmiotowy (petitum)}

Motywem podmiotowym rekursu jest konkretne żądanie autora rekursu skierowane do określonej dykasterii Kurii Rzymskiej. Kodeks prawa kanonicznego z 1983 r. nie precyzuje, jakie możliwe formy może przybrać żądanie autora rekursu. W świetle kan. 1739 KPK, odnoszącym się do decyzji organu hierarchicznego,

10 „Praeterea cognoscit de recursibus, intra terminum peremptorium triginta dierum utilium interpositis, adversus actus administrativos singulares sive a Dicasteriis Curiae Romanae latos sive $\mathrm{ab}$ ipsis probatos, quoties contendatur num actus impugnatus legem aliquam in decernendo vel in procedendo violaverit".

${ }^{11}$ „I ricorsi gerarchici alla Santa Sede contro i decreti amministrativi di autorità ecclesiasticche sono esaminati sia nella legittimità che nel merito dal Dicastero competente, a norma di diritto (cf. CIC cann. 1732-1739; CCEO cann. 995-1005; Cost. Apo. Pastor bonus, art. 19 § 1)”. 
można jednak wyróżnić następujące: żądanie uznania zaskarżonego aktu administracyjnego za nieważny, unieważnienie go, odwołanie, poprawienie, zastąpienie innym lub uchylenie.

\section{PRZEDMIOT REKURSU HIERARCHICZNEGO}

Zgodnie z kan. 1732 Kodeksu prawa kanonicznego z 1983 r. przedmiotem rekursu hierarchicznego mogą być dekrety i wszelkie inne konkretne akty administracyjne wydane w zakresie zewnętrznym pozasądowym, z wyjątkiem tych, które wydane są przez Biskupa Rzymskiego lub przez sam sobór powszechny ${ }^{12}$. Przedmiotem rekursu hierarchicznego mogą być zatem akty administracyjne ordynariuszy oraz innych organów władzy kościelnej posiadających władzę wykonawczą. Co istotne, przedmiotem rekursu może być akt władzy wykonawczej mający charakter konkretny, a więc dotyczący konkretnej osoby lub osób, zawierający w sobie jakąś decyzję (Joannes Paulus II 1988, art. 123 § 1).

W tym miejscu należy zauważyć, że jakkolwiek wszystkie konkretne akty administracyjne wydane w zakresie zewnętrznym pozasądowym mogą stanowić przedmiot rekursu do dykasterii Kurii Rzymskiej, to istnieją akty, które z racji szerokiej dyskrecjonalności ich autora w praktyce trudno byłoby zakwestionować. Taka sytuacja może mieć miejsce, dla przykładu, w odniesieniu do decyzji biskupa diecezjalnego odnoszącej się do odwołania z urzędu wikariusza biskupiego, kanclerza czy notariusza kurialnego. W tym bowiem względzie dyskrecjonalność biskupa diecezji co do nominowania swoich współpracowników, jak i konieczna relacja zaufania wewnętrznego zdają się przeczyć możliwości rozpatrzenia rekursu przeciwko takim decyzjom biskupa diecezji (Miras, Canosa, Baura 2007, 339) $)^{13}$.

\section{PROCEDURA}

Procedura rozpatrzenia rekursu hierarchicznego zawiera w sobie trzy istotne etapy. Są nimi: złożenie rekursu, faza dowodowa i decyzja dykasterii.

${ }^{12}$ Kan. 1732: „Quae in canonibus huius sectionis de decretis statuuntur, eadem applicanda sunt ad omnes administrativos Artus singularis, qui in foro externo extra iudicium datur, iis exceptis, qui ab ipso Romano Pontifice vel ab ipso Consilio Oecumenico ferantur".

${ }^{13}$ „Lo stesso potrebbe accadere anche nel caso di certe provviste (concretamente, gli interventi dell'autorità che si pongono a completamento di altri atti amministrativi: per esempio, dopo aver rimosso un parroco - c. 1746 - il Vescovo diocesano deve provvedere alla situazione del parroco rimosso, cercare un altro ufficio ecc.). E' possibile, ciononostante, ricorrere contro tali atti, dal momento che nulla impedisce che il dicastero, sulla scorta delle motivazioni addotte dal ricorrente, una volta raccolte le necessarie informazioni, consideri giusto e opportuno agire in altro modo". 


\subsection{Złożenie rekursu}

Osoba posiadająca ogólną zdolność prawną oraz konkretną legitymizację do wniesienia rekursu, o ile czuje się pokrzywdzona konkretnym aktem administracyjnym, ma prawo wniesienia rekursu do kompetentnej dykasterii Kurii Rzymskiej w określonym przez prawo terminie. Zgodnie z kan. 1737 § 2 KPK rekurs należy wnieść w terminie zawitym 15 dni użytecznych.

Należy w tym miejscu zauważyć, że jeśli rekurs hierarchiczny dotyczy aktu wydanego przez organ bezpośrednio niższy od kompetentnej dykasterii Kurii Rzymskiej, obowiązują przepisy dotyczące prośby do autora aktu o jego poprawienie lub odwołanie zgodnie z kan. 1734 KPK. Prośba ta, w myśl kan. 1734 § 2, winna być złożona $\mathrm{w}$ terminie zawitym 10 użytecznych dni od zawiadomienia o dekrecie, zgodnie z przepisami prawa ${ }^{14}$. Oznacza to, iż osoba zainteresowana, czyli adresat aktu, traci możliwość wniesienia rekursu hierarchicznego, a jeśli by to uczynił, nie powinien on zostać przyjęty. I rzeczywiście, praktyka Kurii Rzymskiej potwierdza, że w przypadku niewniesienia prośby do autora aktu o jego poprawienie lub odwołanie dykasteria oddala złożony do niej rekurs albo, w wyjątkowych sytuacjach, przesyła do autora aktu administracyjnego celem ustosunkowania się do złożonego rekursu (Miras, Canosa, Baura 2007, 340).

Termin 15 dni użytecznych na złożenie rekursu do dykasterii rzymskiej, w odniesieniu do rekursów, które w myśl kan. 1734 § 3 KPK nie wymagają złożenia uprzedniej prośby do autora aktu o jego poprawienie lub odwołanie, biegnie od dnia zawiadomienia o akcie stającym się przedmiotem rekursu hierarchicznego. W odniesieniu do aktów, które w myśl kan. 1734 § 1 wymagają uprzedniej prośby, o której mowa, termin 15 dni użytecznych biegnie od dnia zawiadomienia o dekrecie, w którym autor aktu pierwszy dekret poprawił lub go odrzucił (kan. 1735 KPK). Natomiast w przypadku aktu, w odniesieniu do którego zastosowano milczenie, pomimo złożenia prośby do jego autora o poprawienie go lub odwołanie, czyli autor nie podjął żadnej decyzji, termin 15 dni użytecznych za złożenie rekursu biegnie od trzydziestego dnia od daty złożenia prośby (kan. $1735 \mathrm{KPK}$ ).

Jeśli w wyznaczonym terminie określona osoba nie jest w stanie złożyć rekursu i zostanie to dowiedzione, dykasteria może poprosić Biskupa Rzymskiego o dyspensę od niezachowania terminu. Jeśli zaś niemożność złożenia rekursu w określonym terminie nie zostanie dowiedziona, rekurs zostanie odrzucony (Miras, Canosa, Baura 2007, 341) ${ }^{15}$.

${ }^{14}$ Kan. $1734 \S 2$ : „Petitio fieri debet intra peremptorium terminum decem dierum utilium a decreto legitime intimatio".

${ }^{15}$ „A motivo della lontananza geografica e della difficoltà di comunicazione, talora sorgono dei problemi assai complessi. Se, per esempio, il ricorrente si trova lontano da Roma e non riceve alcuna risposta, non potrà sapere quando il ricorso è giunto al dicastero, benché, di norma, esso provveda a inviargli un ricontro del ricevimento. In caso contrario, si deve tener conto che, se non viene data 
Generalnie rekurs hierarchiczny winien być złożony przełożonemu ad quem. Może być jednak złożony również przed przełożonym, który wydał zaskarżany akt administracyjny, a ten zobowiązany jest do przesłania go natychmiast do kompetentnej dykasterii (kan. 1737 § $1 \mathrm{KPK}$ ).

Rekurs winien być złożony na piśmie i zawierać wszystkie informacje konieczne do jego rozpatrzenia, a więc wskazywać autora rekursu, autora zaskarżanego aktu oraz akt, który podlega zaskarżeniu. Winien też wskazywać motyw formalny rekursu oraz konkretne żądanie (Ortiz 1999, 77).

Złożenie rekursu może wywoływać zarówno skutek przekazujący (effectus devolutivus), jak i zawieszający (effectus suspensivus). Złożenie rekursu samo w sobie nie zawiesza wykonania aktu administracyjnego, z wyjątkiem przypadków wyraźnie wskazanych przez prawo ${ }^{16}$. O zawieszeniu wykonania aktu może natomiast zdecydować autor aktu administracyjnego na prośbę złożoną przez autora rekursu w ciągu 10 dni od złożenia prośby o poprawienie lub odwołanie aktu (kan. 1736 § 2 KPK) lub dykasteria rzymska (kan. 1737 § 3 KPK).

\subsection{Faza dowodowa}

Zgodnie z kan. 57 § 1 KPK organ administracyjny, do którego został złożony rekurs, ma trzy miesiące od dnia jego otrzymania na wydanie decyzji. Zgodnie z art. 136 § 2 Ogólnego Regulaminu Kurii Rzymskiej dykasteria ma prawo wydłużyć wskazany termin, podając stronom zainteresowanym czas potrzeby na podjęcie decyzji oraz motywy jego wydłużenia.

Materiał dowodowy jest przedstawiany przez zainteresowane podmioty lub też decyzję o jego zebraniu podejmuje dykasteria (kan. 697 § 1-2, 1742 § 1, 1745 KPK). Wszelkie kopie dowodów są przesyłane każdemu z zainteresowanych podmiotów, a ewentualne przesłuchanie autora rekursu lub świadków odbywa się przed urzędnikiem dykasterii, który występuje w postępowaniu administracyjnym jako notariusz, lub przed delegowanym organem sądowniczym miejsca zamieszkania danej osoby. Dykasteria zawsze może zarządzić przesłuchanie autora rekursu w celu bliższego wyjaśnienia sprawy i bardziej dokładnego poznania jego motywacji (kan. 1738 KPK).

Procedura rozpatrzenia rekursu w poszczególnych dykasteriach rzymskich opiera się na normach Ogólnego Regulaminu Kurii Rzymskiej oraz na normach specjalnych każdej z dykasterii (Labendeira 1994, 469). Rekurs pozostający w kompetencji jednej dykasterii jest rozpatrywany i rozstrzygany przez Kongres. Rekurs będący

una risposta entro tre mesi dal giorno della presentazione del ricorso al dicastero e, da tale termine, passano altri trenta giorni, il ricorrente perde il diritto di impugnare presso Segnatura Apostolica".

${ }^{16}$ Kodeks prawa kanonicznego wskazuje na trzy takie przypadki: rekurs od dekretu wydalającego członka instytutu życia konsekrowanego, instytutu świeckiego lub stowarzyszenia życia apostolskiego (kan. 700, 729, 746 KPK), rekurs od dekretu, w którym została wymierzona lub zdeklarowana kara (kan. 1353, 1342 § 2, $1720 \mathrm{KPK}$ ) oraz rekurs od dekretu usunięcia proboszcza (kan. 1747 § 3 KPK). 
w kompetencji dwóch lub więcej dykasterii jest rozpatrywany i rozstrzygany przez zainteresowane kongregacje na posiedzeniu mieszanym, zwyczajnym lub plenarnym.

W celu należytego poznania sprawy i jej rozstrzygnięcia dykasteria korzysta z opinii jednego lub kilku konsultorów (Joannes Paulus II 1988, art. 8; Regolamento generale della Curia Romana 1999, art. 121-122). Po przedstawieniu przez zainteresowane podmioty swoich uwag, Relator sprawy przygotowuje status questionis i informuje o nim Kongres. Jego zadaniem jest też zredagowanie dekretu na podstawie decyzji podjętej przez Kongres (Ortiz 1999, 80).

\subsection{Decyzja organu hierarchicznego}

Zgodnie z kan. 57 § 1 KPK dykasteria winna podjąć decyzję w ciągu trzech miesięcy od otrzymania rekursu. Po upływie tego terminu, zgodnie z normą zawartą w kan. 57 § 2, jeśli nie wydano dekretu, należy domniemywać odpowiedź negatywną w odniesieniu do wszczęcia procedury sądowoadministracyjnej ${ }^{17}$. Co istotne, brak decyzji, zgodnie z kan. 57 § $3 \mathrm{KPK}$, nie zwalnia dykasterii od obowiązku wydania dekretu, a także od obowiązku naprawienia ewentualnej szkody.

Decyzja dykasterii winna być zawsze wydana na piśmie, z podaniem przynajmniej ogólnej motywacji. Potwierdza to norma zawarta w art. 136 § 3 Ogólnego Regulaminu Kurii Rzymskiej z 1999 r. ${ }^{18}$ Nie wydaje się, aby motywacja była wymagana do ważności dekretu, o ile nie jest to wyraźnie stwierdzone w określonej normie (kan. $699 \S 1 \mathrm{KPK}$ ) - wystarczy, aby była to motywacja sumaryczna lub odnosząca autora rekursu do tej podanej w dekrecie zaskarżonym ${ }^{19}$.

Decyzja dykasterii winna być następnie doręczona zgodnie z przepisami prawa (kan. $54 \S 2 \mathrm{KPK})$. W tym względzie nie jest wystarczające przesłanie jedynie samej decyzji, ale integralnego dekretu wraz z zawartą w nim motywacją. Jeśli zaś motywacja, o której mowa, miała jedynie charakter odnoszący się do tej zawartej w zaskarżonym akcie administracyjnym, czyli była dokonana per relationem, należy też załączyć akt z motywacją, do której się ona odnosi (Gullo 1991, 96).

Norma zawarta w kan. 1739 KPK precyzuje poszczególne rodzaje decyzji, jakie może podjąć dykasteria ${ }^{20}$. Dykasteria przede wszystkim może potwierdzić

${ }^{17}$ Kan. $57 \S 2$ : „Hoc termino transacto, si decretum nondum datum fuerit, responsum praesumitur negativum, ad propositionem ulterioris recursus quod attinet".

${ }^{18}$ Art. 136 § 3: „Il Dicastero dece motivare le proprie decisioni circa i ricorsi esaminati, a norma del can. 51 del Codice di Diritto Canonico e del can. $1519 \S 2$ del Codice dei Canoni delle Chiese Orientali".

${ }^{19}$ Kan. 1617: „Ceterce iudicis pronuntiationes, Prater sententiam, sunt decreta, quae si mere ordinatoria non sint, vim non habend, nisi saltem summarie motiva exprimant, vel ad motiva in alio actu Expressa remittant".

${ }^{20}$ Kan. 1739: „Superiori, qui de recursu videt, licet, prout casus ferat, non solum decretum confirmare vel irritum declarare, sed etiam rescindere, revocare, vel, si id Superiori magis expedire videatur, emendare, subrogare, ei obrogare". 
zaskarżony akt, co oznacza oddalenie rekursu. Może następnie stwierdzić niezaistnienie lub nieważność aktu administracyjnego, jeśli akt jest nieistniejący lub nieważny na mocy prawa, tzn. pozbawiony jakiegoś elementu lub przymiotu wymaganego do jego ważności, na podstawie normy zawartej w kan. $124 \S 1 \mathrm{KPK}^{21}$, albo wydany jest przez podmiot absolutnie niemający kompetencji do jego wydania lub zawierający wadę co do formy, skutkującą nieważnością aktu (kan. 10, 65 $\S 3,90 \S 1,125,126,182 \S 2,1331 \S 2$ KPK). Dykasteria może ponadto unieważnić zaskarżony akt z powodu zawartych w nim wad (kan. $125 \S 2,126,149 \S 2$, $166 \S 2$ KPK). Może też odwołać akt, który pomimo że jest zgodny z prawem, jest niestosowny, nieużyteczny czy wręcz szkodliwy (kan. 47, 73, 93 KPK). Zgodnie z kan. 1739 KPK dykasteria może również zaskarżony akt poprawić, jeśli zawiera on błędy (kan. $1734 \S 1,1735$ KPK), wreszcie - może go zastąpić innym, całkiem nowym (kan. 1425 § KPK).

W tym miejscu należy dodać, że jakkolwiek kan. 1739 nie wspomina nic o możliwości orzeczenia dotyczącego naprawienia szkód będących konsekwencją aktu administracyjnego, jest to możliwe zarówno w przypadku zastąpienia aktu innym, jak i jego uchylenia (Ortiz 1999, 83). Możliwość taka wynika jasno z kan. 128, 221 i 144 § 2 KPK (D’Ostilio 1996, 475).

Decyzja definitywna, rozstrzygająca rekurs hierarchiczny w dykasterii Kurii Rzymskiej, rodzi obowiązek podporządkowania się jej po stronie wszystkich zainteresowanych podmiotów. Jeśli zaś któryś z podmiotów uważa, że został pokrzywdzony decyzją rozstrzygającą rekurs hierarchiczny wydaną przez kongregację Kurii Rzymskiej, może wnieść rekurs do II sekcji Sygnatury Apostolskiej lub zwrócić się do papieża z prośbą o łaskę, zwaną beneficium novae audientiae (Krukowski 1985, 218).

Decyzja definitywna wydana przez dykasterię rzymską stanowi zatem ostatnie stadium drogi administracyjnej rozstrzygania sporów administracyjnych w Kościele. Procedura sądowoadministracyjna stosowana w II sekcji Sygnatury Apostolskiej znacząco różni się od procedury administracyjnej, gdyż odnosi się wyłącznie - przynajmniej w zasadniczej treści - do nielegalności aktu administracyjnego. Stanowi jednak uzupełnienie drogi administracyjnej, stając się gwarantem ochrony praw wiernych w Kościele, naruszonych poprzez nielegalnie wydany akt administracyjny. W zakresie merytorycznej oceny takiego aktu dykasterie rzymskie pozostają ostatnim szczeblem sprawiedliwości administracyjnej Kościoła.

${ }^{21}$ „Ad validitatem Artus iuridici requiritur ut a persona habili sit positivus, atque in eodem adsint quae actum ipsum essentialiter constituunt, necnon sollmnia et requisita iure ad validitatem actus imposita". 


\title{
BIBLIOGRAFIA
}

\section{Źródła}

Joannes Paulus II. 1988. „Constitutio apostolica Pastor bonus”. Acta Apostolicae Sedis 80: 841-912. „Lex propria S. Romanae Rotae ac Signaturae Apostolicae”. 1909. Acta Apostolicae Sedis 2: 20-35. Pius X. 1909. „Constitutio apostolica Sapienti consilio”. Acta Apostolicae Sedis 1: 7-19.

Pontificia Commissio Codicis Iuris Canonici Authentice Interpretando. 1988. Acta Apostolicae Sedis 80: 1818.

„Regolamento generale della Curia Romana”. 1999. Acta Apostolicae Sedis 91: 630-699.

\section{Literatura}

D’Ostilio, Francesco. 1996. Il diritto amministrativo della Chiesa. Città del Vaticano: Libreria Editrice Vaticana.

Gullo, Carlo. 1991. „Il ricorso gerarchico: procedura e decisione”. W La giustizia amministrativa nella Chiesa. 86-87. Città del Vaticano: Libreria Editrice Vaticana.

Krukowski, Józef. 1985. Administracja w Kościele. Zarys kościelnego prawa administracyjnego. Lublin: Katolicki Uniwersytet Lubelski, Wydział Prawa Kanonicznego.

Labandeira, Eduardo. 1991. „Il ricorso gerarchico canonico: petitum e causa petendi”. W La giustizia amministrativa nella Chiesa. 71-84. Città del Vaticano: : Libreria Editrice Vaticana.

Labandeira, Eduardo. 1994. Trattato di diritto amministrativo canonico. Milano: Giuffrè.

Lo Castro, Gaetano. 1985. Il soggetto e i suoi diritti nell'ordinamento canonico. Milano: Giuffrè.

Marchesi, Mario. 1996. „I ricorsi gerarchici presso i dicasteri della Curia romana”. Ius Ecclesiae 8: 71-96.

McClunn, Justin. 1946. Administrative Recourse. Washington: The Catholic University of America Press.

Miras, Jorge, Javier Canosa, Eduardo Baura. 2007. Compendio di diritto amministrativo canonico, Roma: Edusc.

Moneta, Paolo. 1991. „I soggetti nel giudizio amministrativo”. W La giustizia amministrativa nella Chiesa. 55-70. Città del Vaticano: Libreria Editrice Vaticana.

Navarro, Luis. 1993. Diritti di associazione e associazione di fedeli. Milano: Giuffrè.

Ortiz, Miguel Angel. 1999. „I ricorsi gerarchici”. W I giudizi nella Chiesa. Processi e procedure speciali. 39-84. Milano: Glossa.

Ranaudo, Arcangelo. 1968. „Il contenzioso amministrativo canonico”. Monitor Ecclesiasticus 93: $547-566$.

pr. Grzegorz Leszczyński

\section{THE HIERARCHICAL RECOURSE TO THE CONGREGATION OF ROMAN CURIA}

\begin{abstract}
The Code of Canon Law of 1983 referring to hierarchical recourse, does not limit it merely to the appeal to the Congregation of Roman Curia, but it refers to each recourse sought in a higher executive administration organ. The subject of interest of the author is the hierarchical recourse sought in the Roman Curia after exhausting the hierarchical path of lower grades. According to can. $1737 \S 1$ of the Code of Canon Law, anyone who considers himself injured with the decree can seek recourse to the hierarchic superior of the one who delivered the decree. Therefore the author is speaking about the subject of the recourse, the motive as well as the procedure to be undertaken in order to obtain the desired goal, appeal or change of the harmful act.
\end{abstract}

Keywords: recurs, Roman Curia, decree, administrative act, procedure. 